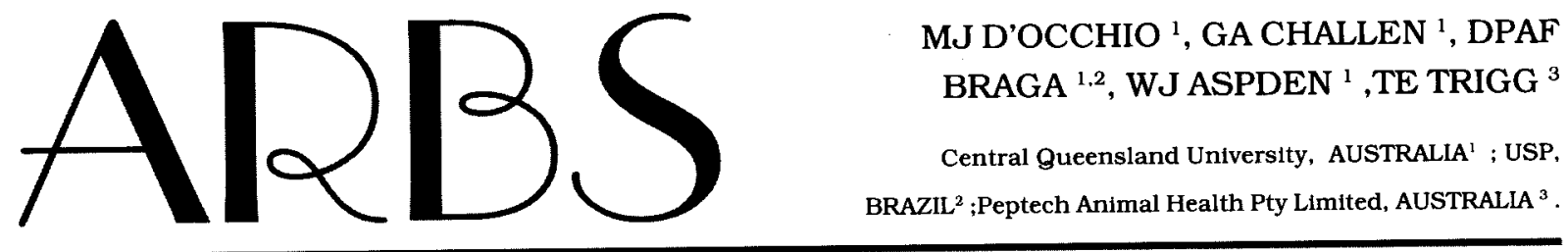

\title{
Post-Transcription Regulation of mRNA and Hormone Synthesis and Release at the Anterior Pituitary Gland: Information derived from the recovery of pituitary gonadotrope cell function after therapy with a GnRH agonist
}

\section{Contents}

Abstract

Introduction

Mechanisms of Post-Transcription Gene Regulation

Premature Termination of Transcription

Alternate mRNA Splicing

mRNA Transport Control

Cytoplasmic mRNA Localization

Translational Control

Selective mRNA Degradation / Control of mRNA Stability

Post-transcription Gene Regulation in the Anterior Pituitary

The Gonadotrope Cells of the Anterior Pituitary

GnRH Binding and Signal Transduction in Gonadotrope Cells

Desensitization of Gonadotrope Cells to GnRH

Response of Gonadotrope Cells to GnRH Agonists

Ovarian Function During GnRH Agonist Therapy

Gonadotrope Cell Function After Therapy With a GnRH Agonist

Ovarian Follicular Growth After Therapy With a GnRH Agonist

Molecular Features of Gonadotrope Cells After Therapy With a GnRH Agonist

Summary

References

Correspondence

MJ D'OCCHIO, GA CHALLEN, WJ ASPEN

Animal Sciences and Production Group and School of Chemical and Biomedical Sciences, Central Gueensland

University, Rockhampton. Queensland, Australia 4701; emall: m.docchio@cqu.edu.au

DPAF BRAGA ${ }^{2}$

Departamento de Reprodução Animal, Faculdade de Medicina Veterinária e Zootecnia, USP, São Paulo, Brazil;

TETRIGG ${ }^{3}$

Peptech Animal Health Pty Limited, North Ryde, Sydney, N.S.W., Australia. 


\section{Abstract}

This review presents a summary of post-transcription regulation of mRNAs with a focus on the anterior pituitary gland. The control of gene transcription and production of mRNAs is the predominant form of regulation of hormone synthesis. However, post-transcription regulation of mRNAs provides another level of control of hormone synthesis. Examples of how hormone synthesis can be controlled at the level of mRNA include mRNA nuclear export and subcellular localization, mRNA stability and turnover, and regulation of mRNA translation. The gonadotrope cells of the anterior pituitary have multiple internal effector systems and provide an ideal model cell to study post-transcription regulation of mRNAs. Gonadotrope cells are stimulated to release LH and FSH by hypothalamic GnRH that binds to GnRH receptors. GnRH receptors are coupled to G-proteins and second messenger signaling pathways that involve cAMP and IP3. These signaling pathways are associated with the release of LH and FSH and transcription of mRNAs for LH and FSH. The stability of these mRNAs can be influenced by androgens, estrogens and progestagens. Therapy with a GnRH agonist leads to desensitization of gonadotrope cells to GnRH and a depletion of cellular stores of LH and FSH mRNAs, and content of LH and FSH. After discontinuation of therapy with GnRH agonist, levels of LH and FSH mRNAs return to normal some time before $\mathrm{LH}$ and FSH content and secretion are restored. This is indicative of post-transcription regulation of LH and FSH mRNAs. Future studies on post-transcription regulation of mRNAs will provide new molecular insights into how gonadotrope cells balance and integrate stimulation by GnRH with feedback modulation by the gonads.

Koy words; post-transcription regulation; mRNA stability; anterlor pituitary gland; GnRH agonist; downregulation; desensitization; ovarian follicular growth. 


\section{Introduction}

The anterior pituitary gland acts as a neuroendocrine transducer and provides an important interface between the brain and somatic endocrine organs that include the thyroid gland, adrenal glands and gonads (Greenspan \& Strewler, 1997). Hypothalamic neuropeptide hormones are released within the basal hypothalamus median eminence and are transported by portal vessels to the anterior pituitary where they act at target cells to stimulate the release of tropic hormones (Greenspan \& Strewler, 1997). For example, the neuropeptide gonadotropin releasing hormone $(\mathrm{GnRH})$ binds to specific receptors on gonadotrope cells in the anterior pituitary to induce release of the two gonadotropic hormones luteinizing hormone (LH) and follicle stimulating hormone (FSH). The response of gonadotrope cells to GnRH has at least two components. One component involves the immediate release of stored LH and FSH whilst a second component involves de novo synthesis of LH and FSH (Hazum \& Conn, 1988; Huckle \& Conn, 1988; Stojilkovic et al., 1994). The latter is associated with second messenger signal transduction and the activation of gene transcription to produce messenger ribonucleic acid (mRNA) for LH and FSH (Huckle \& Conn, 1988; Stojilkovic et al., 1994; Conn et al., 1995) and the GnRH receptor (Lin \& Conn, 1999).

The control of gene transcription and production of mRNAs for tropic hormones has traditionally been considered as the predominant form of regulation of hormone synthesis by cells in the anterior pituitary (Shupnik et al., 1989; Gharib et al., 1990; Theill \& Karim, 1993). However, increasing evidence indicates that posttranscription regulation of mRNAs provides another important level of control of hormone synthesis within the anterior pituitary (Dever 1999; Staton et al., 2000). Examples of how hormone synthesis can be controlled at the level of mRNA include mRNA nuclear export and cytoplasmic localization, mRNA stability and turnover, and regulation of mRNA translation rates (Staton et al., 2000).

The first aim in this review is to provide a general account of posttranscription regulation of mRNAs with particular emphasis on the anterior pituitary gland. The review will then focus on gonadotrope cells and post-transcription regulation of mRNAs for $\mathrm{LH}$ and FSH. Recent studies on the return to normal function by gonadotrope cells after therapy with agonists of GnRH will be used to provide supporting evidence for post-transcription regulation of the mRNA for $\mathrm{LH}$. The reader may find the latter part of the review to be somewhat speculative. This speculation is intended, as two objectives in this review are firstly to raise awareness of posttranscription regulation of mRNAs and hormone synthesis within the context of molecular endocrine function of the anterior pituitary gland, and secondly to stimulate discussion and research in this area. Post-transcription regulation of mRNAs for LH 
and FSH may have important implications in the integrated response of gonadotrope cells to stimulation by GnRH and feedback modulation by the gonads.

\section{Mechanisms of Post-transcription Gene Regulation}

Controls on the initiation of gene transcription are the predominant form of regulation of expression for most genes (Weaver, 1999). However, other controls can act later in the pathway from mRNA production to protein synthesis to modulate the ultimate amount of gene product that is produced (Karp, 1999). Although posttranscription controls (controls that operate after RNA polymerase has bound to the promoter of a gene and begun RNA synthesis) are less common than transcription control points, for many genes post-transcription controls are crucial (Alberts et al., 1994). Growing evidence of pivotal post-transcription regulation for many genes has prompted research to elucidate the mechanisms controlling RNA processing, mRNA nuclear export and localization, mRNA stability and turnover, and mRNA translation rates and post-translation events (Staton et al., 2000). Several major post-transcription regulatory points have been identified and are summarized below (Alberts et al., 1994).

\section{Promature Termination of Transcription}

In eukaryotes, proteins that assemble at the promoter of a gene appear to determine whether or not the polymerase will be able to pass through potential sites of premature termination downstream (Alberts et al., 1994). These proteins can differ between cell types and allow cells to differentially control the attenuation of transcription for particular genes (Jones, 1989).

\section{Alternate mRNA Splicing}

In the simplest examples, regulated alternate mRNA splicing is used to switch from the production of a nonfunctional protein to the production of a functional protein and vice versa (Kornblihtt, 1996). mRNA splicing can be regulated either negatively (by a regulatory molecule that prevents the splicing machinery from gaining access to a particular splice site on the mRNA) or positively (by a regulatory molecule that directs the splicing machinery to an otherwise overlooked splice site) (Rio, 1992). Moreover, alternative mRNA splicing can generate different proteins from the same primary transcript in different cell types according to the requirements and functions of the particular cell (McKeown, 1992). 


\section{mRNA Transport Control}

A substantial fraction of primary transcripts may be completely degraded In the nucleus without ever generating a mRNA that reaches the cytoplasm, either because the mRNA is selectively targeted for intra-nuclear degradation or because the exit of the mRNA from the nucleus is selectively blocked. It was recently shown that the nuclear protein poly(A)-binding protein II (PABP2) binds at high affinity with incipient poly(A) tails, initiating extension and regulating their length (Calado et al., 2000). PABP2 then interacts with the nuclear export mechanism and appears to be involved in mRNA transport to the cytoplasm. In the cytoplasm PABP2 is exchanged for another poly(A)-binding protein (PABP) on the poly(A) tail by an unknown mechanism. PABP2 is then actively returned to the nucleus by a carrier system (Calado et al., 2000). It cannot be excluded that the availability of transcribed mRNA at the ribosomes for translation may be regulated by transport rate and availability of PABP2.

\section{Cytoplasmic mRNA Localization}

In some cases, mRNAs are directed to specific subcellular sites in the cytoplasm by signals in the mRNA sequence itself, before the sequence has been translated (St. Johnston, 1995). The signal is typically located in the 3' untranslated region (UTR) of the mRNA molecule (Kislaushis \& Singer, 1992). This is a region that extends from the stop codon that terminates protein synthesis to the start of the poly-A tail. It is still unclear how many mRNAs are localized in this way and it is presumably advantageous for the cell to position its mRNA close to the subcellular sites where the protein produced from the mRNA is required.

\section{Translational Control}

Poly(A)-binding protein (PABP) which bonds with the poly(A)-tail of a mRNA in the cytoplasm has been shown to be an initiator of translation (Deo et al., 1999). In recent studies, PABP interacted with a eukaryotic translation factor $4 \mathrm{G}$ (eIF4G) to facilitate initiation of translation of polyadenylated mRNAs (Korneeva et al., 2000; Pyronnet S, 2000; Wakiyama et al., 2000). Additionally, some mRNAs have been shown to contain a major protein-coding region determinant of instability (mCRD) involved in regulation of mRNA translation (Grosset et al., 2000). Specific translation repressor proteins that bind near the 5' end of the mRNAs, where translation would otherwise begin, block the translation of some mRNA molecules (Melefors \& Hentze, 1993). In eukaryotic cells, a particularly well characterized form of negative translational control allows the synthesis of the intracellular iron storage protein ferritin to be increased rapidly if the level of soluble iron atoms in the cytoplasm rises (Thompson et al., 1999). 


\section{Selective mRNA Degradation / Control of mRNA Stability}

Degradation of mRNA is not a random, unregulated nuclease breakdown process, but instead is precisely controlled and regulated by a number of specific modifying mRNA sequences and structures (cis elements) and RNA-binding proteins (trans elements) (Brooks and Rigby, 2000). The stability of a mRNA molecule can be changed in response to intra- and extra-cellular signals, such that cytoplasmic mRNA levels often correlate more closely with transcript stability rather than transcription rate (Weaver, 1999). Nucleases, mRNA sequence elements and regulated RNA-binding proteins required for the promotion or inhibition of mRNA decay have been identified and the molecular mechanisms involved are being elucidated (Staton et al., 2000). Generally, mRNA decay can be triggered by at least one of three types of initiating events: poly-A tail shortening, arrest of translation at a premature nonsense codon, and endonucleolytic cleavage (Stevens, 1993). Poly(A)-binding protein (PABP) has been shown to be a regulator of both mRNA stabilization and degradation (Deo et al., 1999). PABP along with a stability protein have been shown to be important in protecting the body of the alpha-globin mRNA from endonuclease cleavage (Wang et al., 1999; Wang \& Kiledjian, 2000). Five proteins associated with the mRNA major protein-coding region determinant of instability (mCRD) have been identified that stabilized mRNA containing mCRD by blocking deadenylation (Grosset et al., 2000).

\section{Post-transcription Gene Regulation in the Anterior Pituitary}

Selective mRNA degradation, hormonal regulation of mRNA stability, and RNA-protein interactions in the anterior pituitary have been the subject of a recent review (Staton et al., 2000). A large number of genes expressed in the anterior pituitary are regulated at the level of mRNA stability. In gonadotrope cells, the half-lives of FSH $\beta$-subunit, glycoprotein $\alpha$-subunit and LH $\beta$-subunit mRNAs were found to be 1.0, 6.5 and 44 hours respectively in cultured rat pituitary cells (Bouamoud et al., 1992). However, the stability of these mRNAs could be altered by various factors. For example, steroid hormones were shown to influence the stability of a number of anterior pituitary mRNAs (Table 1). FSH $\beta$-subunit mRNA was stabilized 2 -fold by testosterone in male rat gonadotrope cells, whereas testosterone had no apparent effects on LH $\beta$-subunit mRNA or the common $\alpha$-subunit mRNA (Paul et al., 1990). Estrogens and progesterone augmented the effects of GnRH in stabilizing LH $\beta$-subunit mRNA in the rat (Park et al., 1996). In gonadotrope-derived $\alpha \mathrm{T}_{3}$ cells, the stability of the gonadotropin $\alpha$-subunit mRNA was increased approximately 6 -fold in the presence of GnRH (Chedrese et al., 1994). Rapid disappearance of the above mRNAs was associated with a progressive shortening of the poly-A tail (Bouamoud et al., 1992), an effect that may be prevented or attenuated in the presence of steroid hormones. 


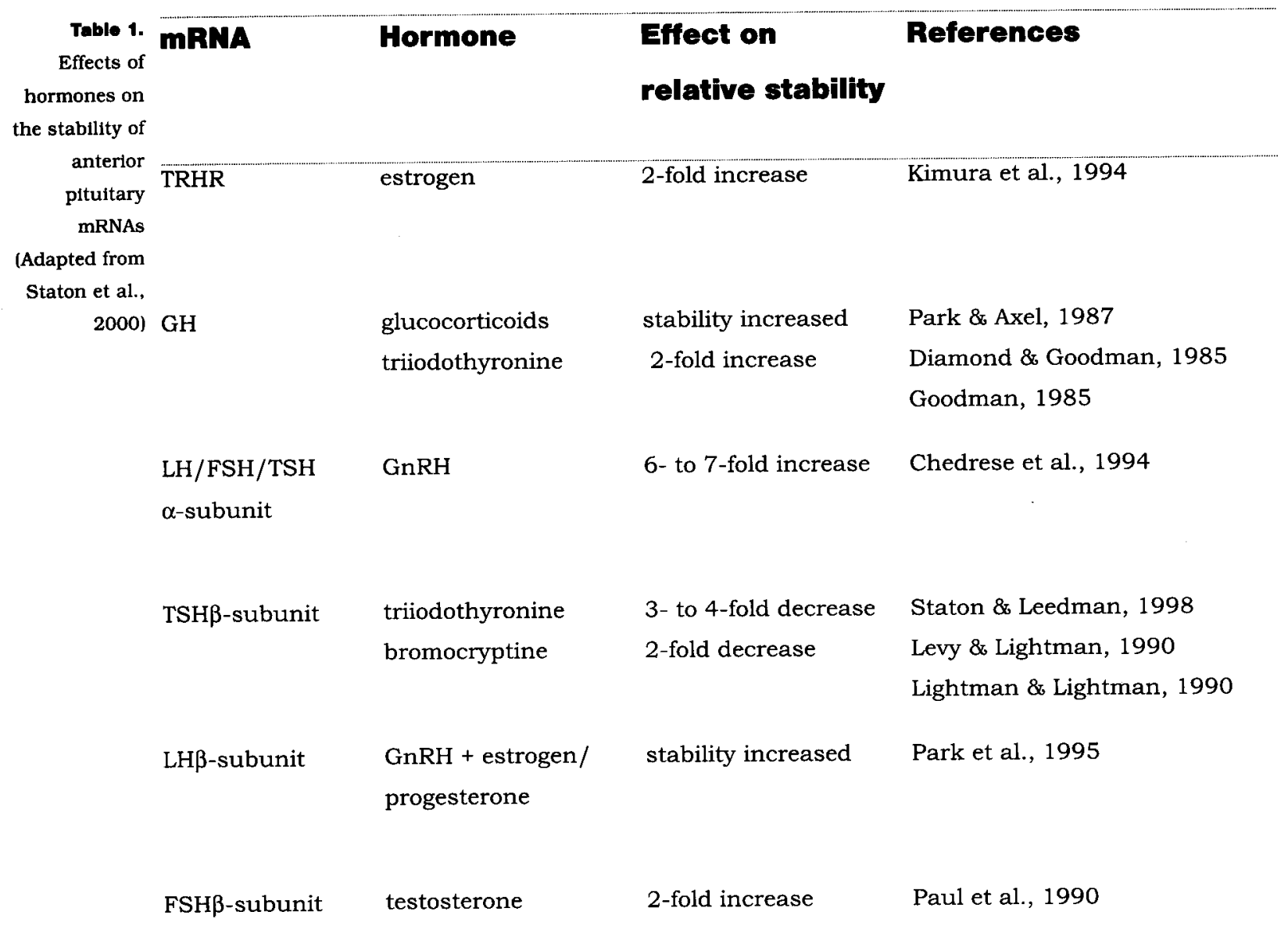

TRHR, thyrotropin releasing hormone receptor; GH, growth hormone; TSH, thyroid stimulating hormone

Specific RNA-binding proteins that target several different mRNAs including TSH $\beta$ subunit mRNA and thyrotropin-releasing hormone receptor mRNA in thyrotrope cells have been characterized in the anterior pituitary (Leedman et al., 1995).

\section{The Gonadotrope Cells of the Anterior Pituitary}

The above discussion has attempted to provide a general overview of the mechanisms of post-transcription regulation of mRNAs. The remainder of the review will focus on the gonadotrope cells of the anterior pituitary. One reason for this focus is that gonadotrope cells serve as intermediary neuroendocrine transducers of communication between the brain and gonads. As noted earlier, gonadotrope cells are stimulated by the hypothalamic neuropeptide $\mathrm{GnRH}$ to release the gonadotropic 
hormones $\mathrm{LH}$ and FSH. These gonadotropins control the steroidogenic and gametogenic functions of the ovaries and testes (Johnson \& Everitt, 2000). The release of LH and FSH from gonadotrope cells at any point in time reflects a balance between stimulation from GnRH and feedback modulation by the gonads (Johnson \& Everitt, 2000). The binding of GnRH to gonadotrope cells initiates multiple second messenger signal transduction pathways that influence $\mathrm{LH}$ and FSH release, and LH and FSH biosynthesis (Hazum \& Conn, 1988; Huckle \& Conn, 1988). Therefore, there are many potential control points where post-transcription regulation of mRNAs can occur to alter gonadotrope cell function. In the following section a summary is provided of GnRH binding to gonadotrope cells and second messenger signal transduction pathways. This is relatively established information but it is included in the review as it provides a useful background when considering more recent studies that have provided evidence for post-transcription regulation of $\mathrm{LH}$ and FSH $\alpha$ - and $\beta$-subunit mRNAs in gonadotrope cells. Also, a clear understanding of signal transduction and biosynthetic mechanisms within gonadotrope cells will be important in the development of future research on the regulation of mRNAs.

\section{GnRH Binding and Signal Transduction in Gonadotrope Cells}

The GnRH receptor on the surface of gonadotrope cells is a member of the 7-transmembrane $G$ protein-coupled receptor family (Hazum \& Conn, 1988; Benard et al., 2000). Binding of natural sequence GnRH to $\mathrm{GnRH}$ receptors provokes activation and dissociation of intracellular G-protein moieties associated with the receptor, and dimerization of adjacent GnRH-receptor complexes (Hazum \& Conn, 1988; Dan-Cohen et al., 1990). The latter leads to the formation of GnRH-receptor clusters in a process called microaggregation (Conn, 1986; Cornea et al., 2000). GnRH-receptor clusters are targeted for internalization into the gonadotrope cell via clathrin-coated vesicles in a process that appears to be at least partly mediated by $\beta$ arrestin (McArdle et al., 1999). The internalized GnRH receptors are shuttled to endosomes where most are induced to discharge GnRH by the acidic environment (Hazum \& Conn, 1988). The free (re-sensitized) GnRH receptors are recycled back to the cell surface through secretory granules while the GnRH-receptor complexes that do not disassociate are destined for degradation in lysozomes (Hazum \& Conn, 1988). Thus, with continuous exposure to high concentrations of GnRH, the number of cell surface receptors gradually decreases (receptor downregulation) with a concomitant decrease in the sensitivity of the gonadotrope cell to GnRH.

Multiple second messengers were shown to operate within gonadotrope cells as a consequence of GnRH binding (Naor, 1990; Shacham et al., 1999; Benard et al., 2000). The activated G-proteins phosphorylate and activate one or more isoforms 
of phospholipase $\mathrm{C}$, a membrane-bound enzyme which hydrolyses the membrane phospholipid phosphatidylinositol-4,5-bis-phosphate to yield both 1,2-diacylglycerol (DAG) and inositol-1,4,5-triphosphate (IP3) (McArdle et al., 1999). Further steps in the signaling pathway lead to release of sequestered calcium ions $\left(\mathrm{Ca}^{2+}\right)$ from the endoplasmic reticulum (Naor, 1990), activation of receptor-regulated voltagedependent $\mathrm{Ca}^{2+}$ channels in the cell membrane (Clayton, 1989), protein kinase C activation (Huckle \& Conn, 1988), synthesis of arachidonic acid and eicosanoids (Greenspan \& Strewler, 1997), and adenylate cyclase activation and cAMP generation (Counis \& Jutisz, 1991). These second messenger pathways determine the cellular responses of gonadotrope cells to GnRH binding. These responses include exocytosis of secretory vesicles containing stored gonadotropins, gonadotropin biosynthesis, and GnRH-receptor biosynthesis (Sealfon et al., 1997). Hence, there is a multitude of intermediary steps between GnRH binding to specific GnRH receptors on gonadotrope cell, and $\mathrm{LH}$ and FSH biosynthesis and release, that could potentially be influenced by post-transcription regulation of mRNAs.

\section{Desensitization of Gonadotrope Cells to GnRH}

As noted above, the binding of GnRH to receptors on gonadotrope cells provokes internalization of dimerized GnRH-receptor complexes. This leads to a depletion of GnRH receptors on the surface of gonadotrope cells (receptor downregulation) and the cells become transiently insensitive to further stimulation by GnRH (Clayton, 1989). Under normal circumstances, GnRH receptors are replenished and the sensitivity of gonadotrope cells to GnRH is restored (Hazum \& Conn, 1988). Desensitization of gonadotrope cells can also occur when receptor internalization is blocked and desensitization persists after GnRH receptor numbers have returned to typical levels (Huckle \& Conn, 1988). Thus, desensitization is only partly explained by receptor loss and must also involve disruption of post-receptor transduction / effector mechanisms.

Chronic desensitization is associated with a marked depletion of pituitary stores of LH and FSH (Clayton, 1989) implying that gonadotropin biosynthesis is inhibited or substantially reduced in desensitized gonadotrope cells (Laloz et al., 1988). LH $\beta$-subunit and FSH $\beta$-subunit mRNA content are also substantially reduced in desensitized pituitaries (Aspden et al., 1996). Therefore, the cellular basis for desensitization is complex and includes receptor down-regulation, uncoupling of receptor-effector transduction pathways, and inhibition of gonadotropin biosynthesis.

\section{Response of Gonadotrope Cells to GnRH Agonists}

Agonists of GnRH are characterized by a longer half-life in circulation and greater affinity for the GnRH receptor compared with natural sequence GnRH 
(Karten \& Rivier 1986). Chronic therapy with a GnRH agonist results in a sustained downregulation of GnRH receptors on gonadotrope cells (Melson et al., 1986; Hazum \& Conn, 1988; Huckle \& Conn 1988) and desensitization of the cells to endogenous and exogenous natural sequence GnRH (Melson et al., 1986; D'Occhio \& Aspden, 1996; Aspden et al., 1997 ). This is associated with reduced content of LH $\beta$-subunit and FSH $\beta$-subunit mRNA (Aspden et al., 1996) and also LH and FSH (Melson et al., 1986; Aspden et al., 1997 ${ }^{\text {a }}$. Additionally, pulsatile secretion of LH and FSH is lacking (Melson et al., 1986; D’Occhio \& Aspden, 1996). The desensitized condition of gonadotrope cells can be maintained long-term provided that GnRH agonist is present at threshold concentrations in circulation (D’Occhio \& Aspden, 1996, 1999; D'Occhio et al., 2000).

\section{Ovarian Function During GnRH Agonist Therapy}

As a consequence of the lack of pulsatile secretion of LH and FSH during therapy with a GnRH agonist, ovarian follicular growth in females receiving agonist is restricted to the gonadotropin-independent, early antral stage (Gong et al., 1995, Gong et al., 1996). This has led to the use of GnRH agonist pre-treatment to suppress endogenous gonadotropin secretion and ovarian function in women, prior to superstimulation of ovarian follicular growth with exogenous gonadotropins followed by oocyte recovery for IVF procedures (Beckers et al., 2000). A similar application of GnRH agonists to control pituitary secretion of $\mathrm{LH}$ and FSH has been tested in animal models during superstimulation of ovarian follicular growth (D'Occhio \& Aspden 1999; D'Occhio et al., 1999). In other animal models, GnRH agonists have been evaluated for their potential as non-surgical contraception (D'Occhio \& Aspden 1999; Bertschinger et al., 2000; Munson et al., 2000; Trigg et al., 2000).

\section{Gonadotrope Cell Function After Therapy With a GnRH Agonist}

In both human and animal models, exposure to a GnRH agonist is associated with a delay in the capacity of the gonadotrope cells to secrete normal amounts of gonadotropins after the discontinuation of agonist therapy. In women, this delay is manifested in reduced secretion of progesterone during the luteal phase of the ovarian cycle immediately subsequent to therapy with a GnRH agonist (Beckers et al., 2000). Female cattle treated with a GnRH agonist for 28 or 56 days showed a delay of approximately 3 weeks before the occurrence of ovulation (D'Occhio et al., 1996). The delay in return to normal ovarian function in cattle previously treated with a GnRH agonist is considered to be due to ongoing dysfunction of gonadotrope cells. rather than an abnormality at the ovaries. This understanding was supported 
Figure 1.Ovarian follicular growth in response to acute stimulation with FSH from Day 0 to Day 3 in control female cattle (top panel) and female cattle undergoing therapy with a GnRH agonist for approximately 6 months (bottom panel) (M.J. D'Occhio \& F. Cremonesi, unpublished results).
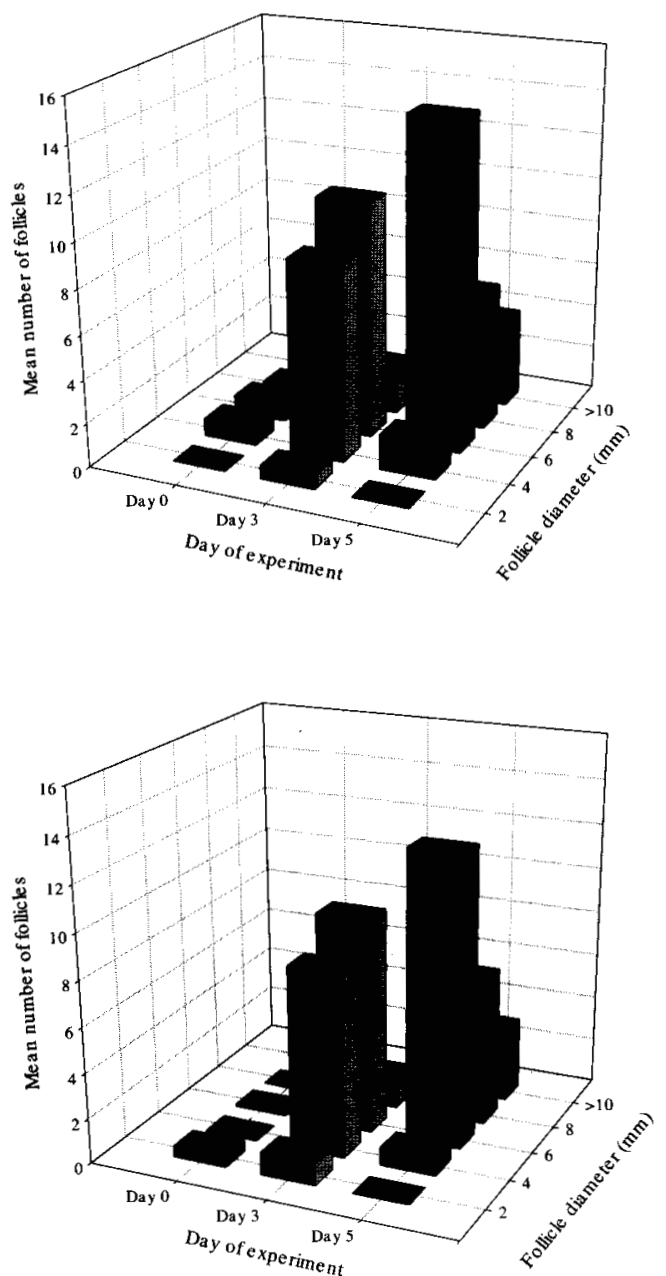

by the observation of apparent normal follicular growth in response to acute therapy with exogenous FSH in female cattle receiving a GnRH agonist, and that had only early antral follicles at the start of FSH therapy (Figure 1). In the latter study, follicles were induced to ovulate by injection of exogenous LH further suggesting that the preovulatory follicles had normal features (M.J. D'Occhio, unpublished results). In another study in female cattle, the response of gonadotrope cells to exogenous GnRH remained suppressed until 12 days after the end of therapy with agonist (Bergfeld et al., 1996; Figure 2). In a complementary group of male cattle, the response of gonadotrope cells continued to be suppressed at 20 days after the end of therapy with a GnRH agonist (Bergfeld et al., 1996 ${ }^{\text {b }}$ Figure 2). The reason(s) for the delay in capacity of gonadotrope cells to secrete LH and FSH after therapy with a GnRH agonist is not understood, but may be related to a delay in the replenishment of LH stores which is discussed later in this review. 


$$
\begin{array}{r}
\text { Figure 2. Increases } \\
\text { in plasma } \\
\text { concentrations of } \\
\text { LH after injection of } \\
50 \mu g \text { natural } \\
\text { sequence GnRH in } \\
\text { control cattle (left } \\
\text { panels) and cattle } \\
\text { previously treated } \\
\text { with a GnRH } \\
\text { agonist for } 28 \text { Days } \\
\text { (right panels). } \\
\text { Results (mean } \pm \\
\text { SEM) for female } \\
\text { cattle are shown in } \\
\text { the top panels and } \\
\text { male cattle in the } \\
\text { bottom panels. The } \\
\text { time in days } \\
\text { represents days } \\
\text { after the }
\end{array}
$$
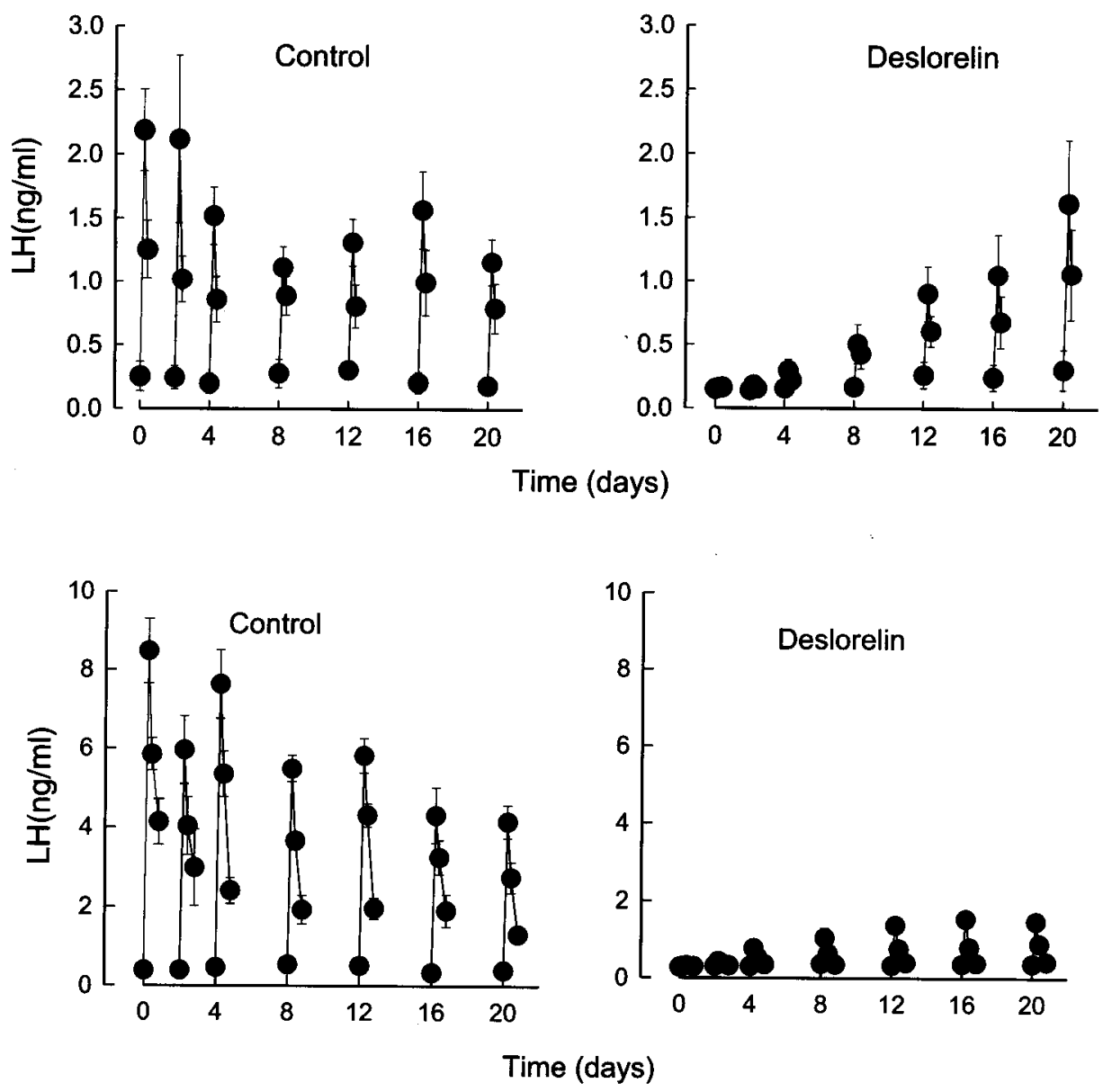

\section{Ovarian Follicular Growth After Therapy With a GnRH Agonist}

Further evidence of continued dysfunction of gonadotrope cells after therapy with a GnRH agonist was provided by the development of persistent large follicles in female cattle. A high proportion of female cattle treated with a GnRH agonist for approximately 6 months developed large follicles ranging in size from 15 to $25 \mathrm{~mm}$ that did not ovulate, but underwent regression between 10 to 20 days after reaching maximal size (Figure 3). These large follicles continued to occur for greater than 50 days after the end of agonist therapy (Figure 4). It would appear that subsequent to therapy with a GnRH agonist, FSH secretion necessary to initiate an ovarian follicular wave is restored some time before gonadotrope cells acquire the capacity to release a surge of LH required for ovulation. The possibility that the occurrence of persistent large follicles in the above studies was the result of ovarian dysfunction cannot be excluded. For example, the follicles may fail to secrete sufficient estradiol required to induce a pre-ovulatory surge release of LH. However, the likelihood of intrinsic ovarian dysfunction subsequent to therapy with a GnRH agonist 
Figure 3.

Representative ultrasound images of follicular growth in female cattle after the discontinuation of therapy with a GnRH agonist. The top left panel is at $\mathbf{3 6}$ days and shows large follicles on both the left ( $18 \mathrm{~mm}$ ) and right ( $15 \mathrm{~mm}$ ) ovaries; top right panel is at $\mathbf{5 2}$ days and shows two large $(20 \mathrm{~mm}$ and $25 \mathrm{~mm}$ )

follicles on the left ovary; bottom left panel is at 16 days and shows a large $(25 \mathrm{~mm})$ follicle on the left

ovary; bottom right panel is at
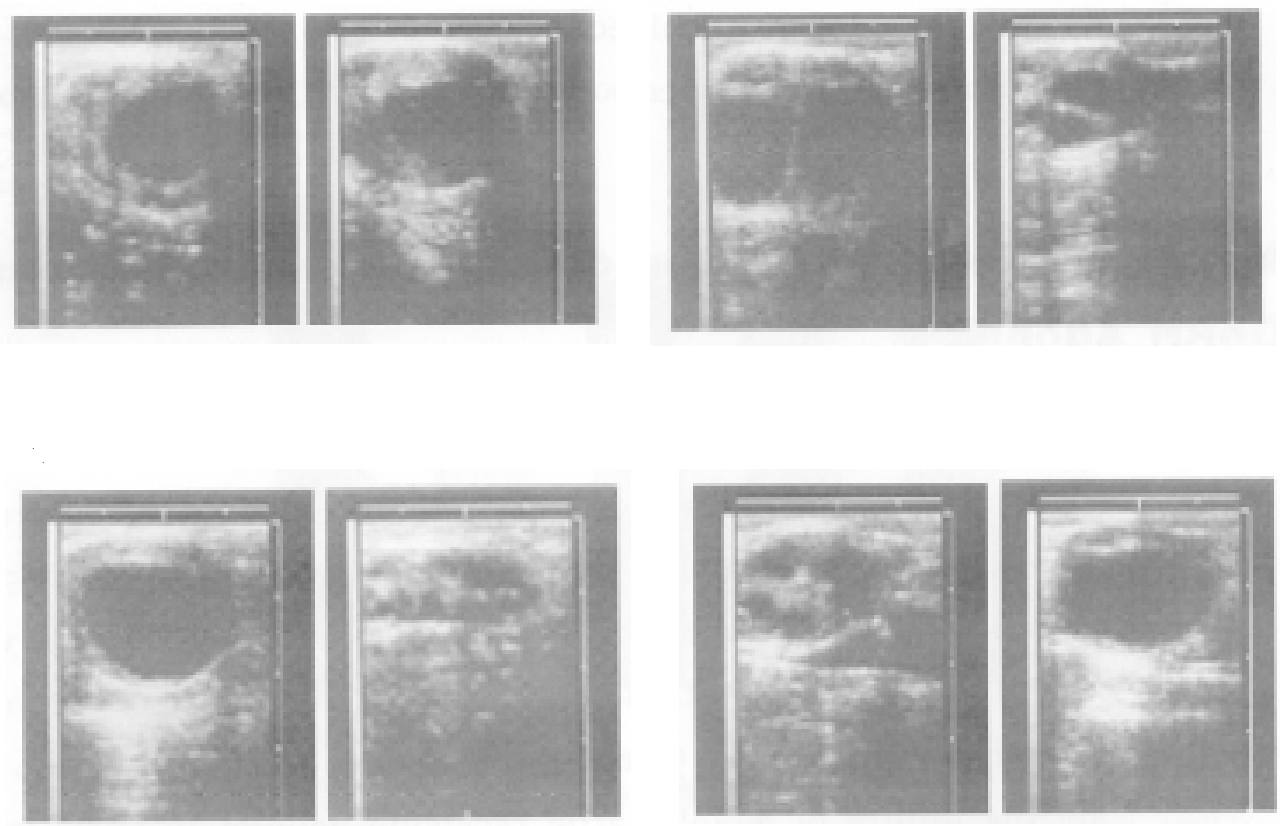

Figure 4. The

transition in

ovarian

follicular status

from early

antral follicles

(2-4 mm) to

occurrence of relatively large

(> $14 \mathrm{~mm}$ )

persistent

follicles in

female cattle

subsequent to

therapy with a

GnRH agonist

(D.P.A.F Braga

and M.J.

D'Occhio,

unpublished

results)

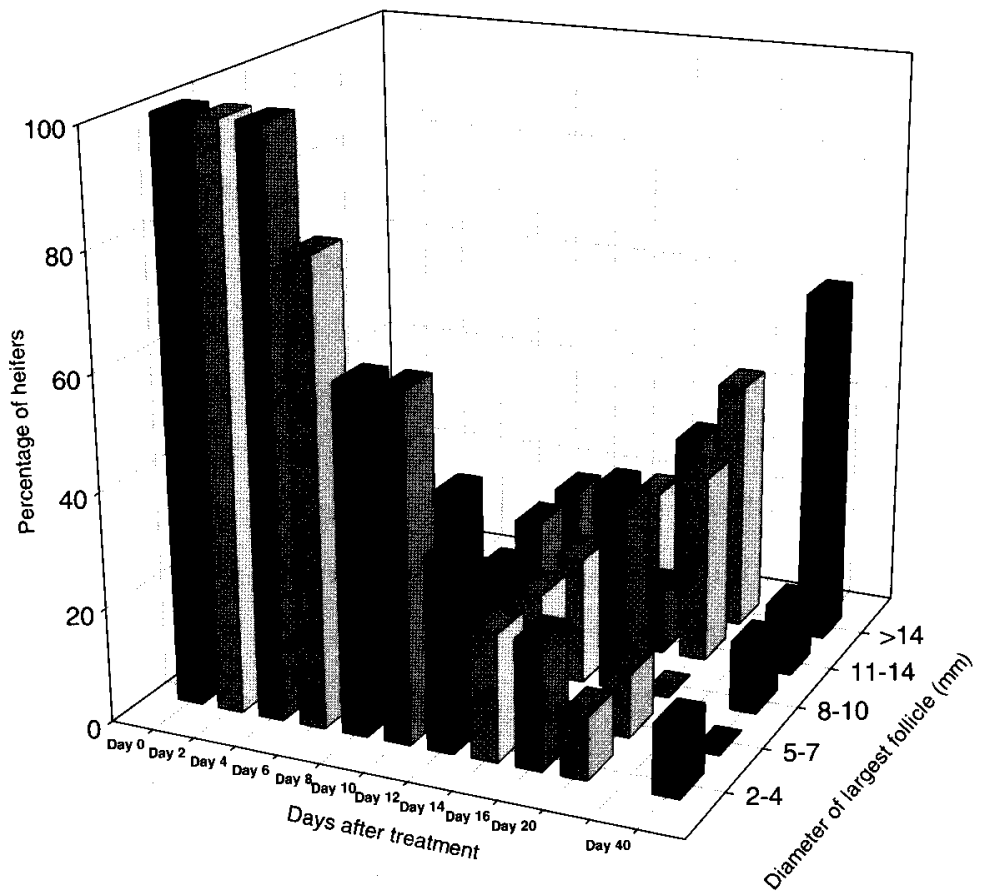


is considered unlikely. As noted above, female cattle receiving a GnRH agonist showed apparently normal follicular growth when treated acutely with FSH (Figure 1), and these follicles ovulated in response to injection of exogenous $\mathrm{LH}$ and developed into apparently normal corpora lutea (M.J. D’Occhio, unpublished results).

\section{Molecular Features of Gonadotrope Cells After Therapy With a OnRH Agonist}

The molecular features of gonadotrope cells after therapy with a GnRH agonist were recently studied in female cattle. Female cattle were treated with GnRH agonist for approximately 3 months, after which time therapy was discontinued and gonadotrope cell function was evaluated over approximately 8 weeks by measuring GnRH receptor mRNA, LH $\beta$-subunit mRNA and pituitary LH content. Therapy with GnRH agonist caused a desensitization of the anterior pituitary. This was illustrated by the failure of female cattle receiving agonist to show increases in plasma concentrations of LH and FSH after injection of natural sequence GnRH compared with untreated females $(\Delta \mathrm{LH}, 0.11 \pm 0.05 \mathrm{ng} / \mathrm{ml}$ and $1.78 \pm 0.34 \mathrm{ng} / \mathrm{ml}$, respectively, $\mathrm{P}<0.01 ; \Delta \mathrm{FSH}, 0.09 \pm 0.05 \mathrm{ng} / \mathrm{ml}$ and $0.41 \pm 0.09 \mathrm{ng} / \mathrm{ml}$, respectively, $\mathrm{P}<0.01$ ). After therapy with GnRH agonist for 3 months, female cattle had reduced pituitary content of GnRH receptor mRNA (Figure 5), LH $\beta$-subunit mRNA (Figure 6) and LH (Figure 7). Pituitary content of GnRH receptor mRNA (Figure 5; Table 2) and LH $\beta$ subunit mRNA (Figure 6; Table 2) had returned to normal levels within 3 days after the discontinuation of agonist therapy. In contrast, pituitary content of LH remained suppressed at 14 days after the end of therapy with GnRH agonist, but had returned to normal levels by Day 28 (Figure 7; Table 2).

These recent findings were interpreted to suggest that biosynthesis of $\mathrm{LH}$ includes post-transcription regulation of $L H \quad \beta$-subunit mRNA. Potential regulation points could include post-transcription mRNA splicing, export from the nucleus to the cytoplasm, and/or control of LH $\beta$-subunit mRNA translation by RNA binding proteins that were discussed earlier. The apparent disassociation in the time-course of return to normal levels of $L H \beta$-subunit mRNA and LH content, would suggest that therapy with a GnRH agonist has a differential effect on transcription regulation of the LH gene, and mechanisms associated with translation of LH $\beta$-subunit mRNA.

In the above study, pituitary LH content had returned to normal levels by Day 28 after the discontinuation of therapy with GnRH agonist (Table 2). At this time, 4 of the 7 females had one or more relatively large ( $\geq 14 \mathrm{~mm}$ diameter) follicles present on their ovaries. It would appear, therefore, that replenishment of gonadotrope cell LH content to normal levels may not necessarily be associated with normal LH 
Figure 5. Relative pituitary GnRH receptor mRNA content in control female cattle and in female cattie previously treated with a GnRH agonist for 91 days. Also shown (right bar) are data for animals that continued to receive GnRH agonist for 147 days. Results are means \pm SEM and numbers signify number of animals IG.A. Challen \& M.J. D'Occhio, unpublished results).

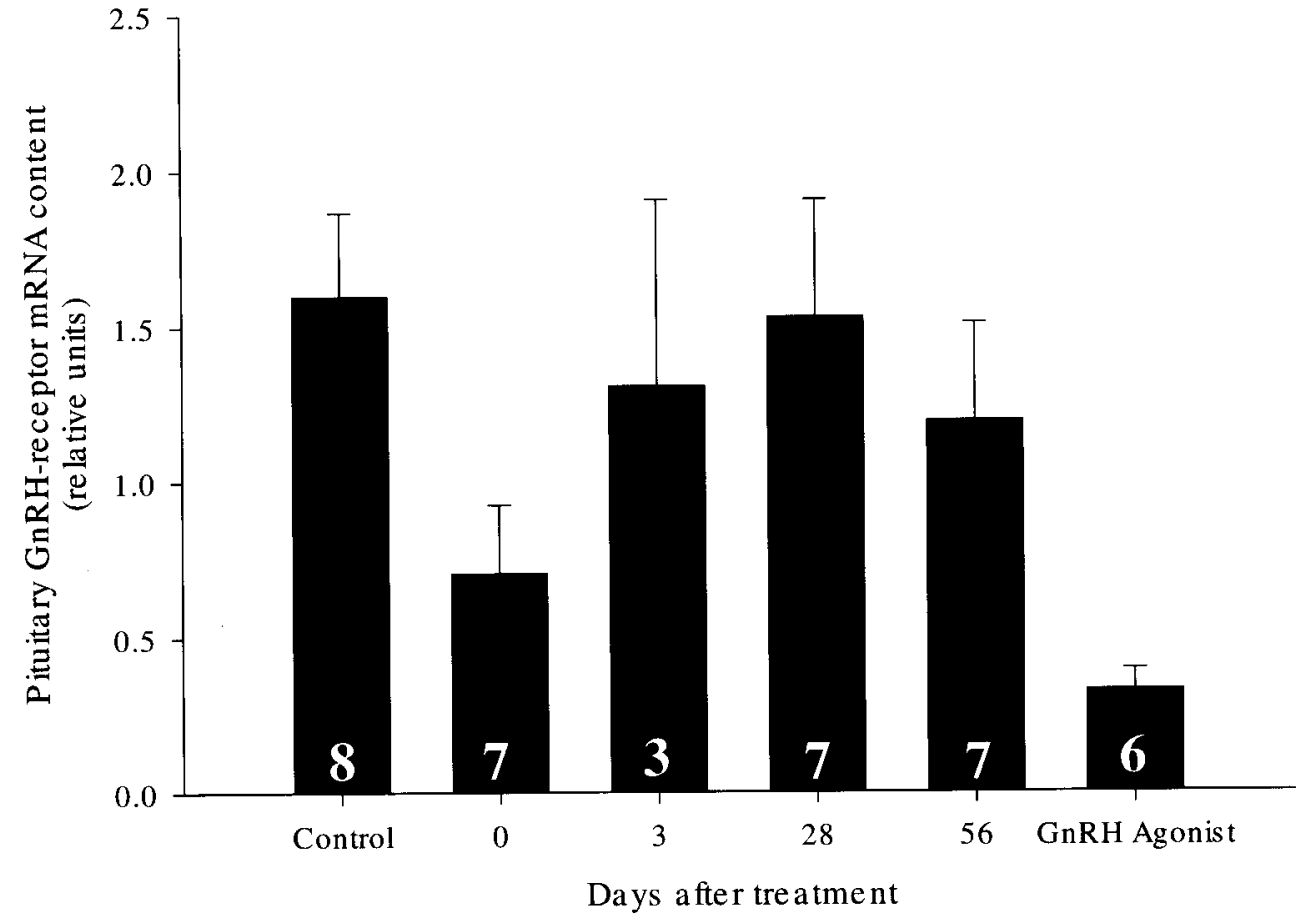

Table 2. Pituitary contents (mean \pm SEM) of GnRH receptor mRNA (relative units), LH $\beta$-subunit mRNA (relative units) and LH (ng/mg tissue) in female cattle during and after therapy with a GnRH agonist. Therapy with GnRH agonist involved a controlled release GnRH agonist implant that was placed subcutaneous in the ear for 91 days IG.A. Challen \& M.J. D'Occhio, unpublished results).
Days after the discontinuation of GnRH agonist therapy

\begin{tabular}{|c|c|c|c|c|c|c|}
\hline Parameter & Control & 0 & 3 & 28 & 56 & $\begin{array}{c}\text { Continued } \\
\text { therapy with } \\
\text { GnRH } \\
\text { agonist (Day } \\
\text { 147) }\end{array}$ \\
\hline $\begin{array}{l}\text { GnRH } \\
\text { receptor } \\
\text { mRNA }\end{array}$ & $1.60 \pm 0.27 \mathrm{a}$ & $0.70 \pm 0.22 \mathrm{b,c}$ & $1.31 \pm 0.60 \mathrm{a}, \mathrm{b}$ & $1.53 \pm 0.38 \mathrm{a}, \mathrm{b}$ & $1.19 \pm 0.32 \mathrm{a,b}$ & $0.33 \pm 0.07 c$ \\
\hline $\begin{array}{l}\text { LH } \beta \text {-subunit } \\
\text { mRNA }\end{array}$ & $1.47 \pm 0.11 \mathrm{a}$ & $0.74 \pm 0.09 \mathrm{~b}$ & $1.68 \pm 0.22 \mathrm{a}$ & $1.36 \pm 0.25 \mathrm{a}$ & $1.37 \pm 0.10^{\mathrm{a}}$ & $0.77 \pm 0.19 b$ \\
\hline $\mathrm{LH}_{\text {content }}{ }^{\dagger}$ & $192 \pm 8 a$ & $106 \pm 15 b$ & $126 \pm 16^{b, c}$ & $156 \pm 11$ a,c,d,e & $187 \pm 24$ a & $134 \pm 13^{\cdot b, c}$ \\
\hline
\end{tabular}

+Pituitary LH content on Day $7(108 \pm 13)$ and Day $14(131 \pm 14)$ after the discontinuation of GnRH agonist therapy was lower $(\mathrm{P}<0.05)$ than for control females.

a.b., , d.e means within rows without a common superscipt differ $(\mathrm{P}<0.05)$ 


\section{Figure 6. Relative}

pituitary LH $\beta$ -

subunit mRNA

content in control

female cattle and in

female cattle

previously treated

with a GnRH agonist

for 91 days. Also

shown (right bar)

are data for animals

that continued to

receive GinRH

agonist for 147

days. Results are

means \pm SEM and

numbers signify

number of animals

(G.A. Challen \& M.J. D'Occhio,

unpublished

results).

Figure 7. Pituitary

LH content in

control female cattle and in female

cattle previously

treated with a

GnRH agonist for

91 days. Also

shown (right bar)

are data for

animals that

continued to

receive $\mathrm{GnRH}$

agonist for 147

days. Results are

means \pm SEM and

numbers signify

number of animals

(G.A. Challen \&

M.J. D'Occhio,

unpublished

results).
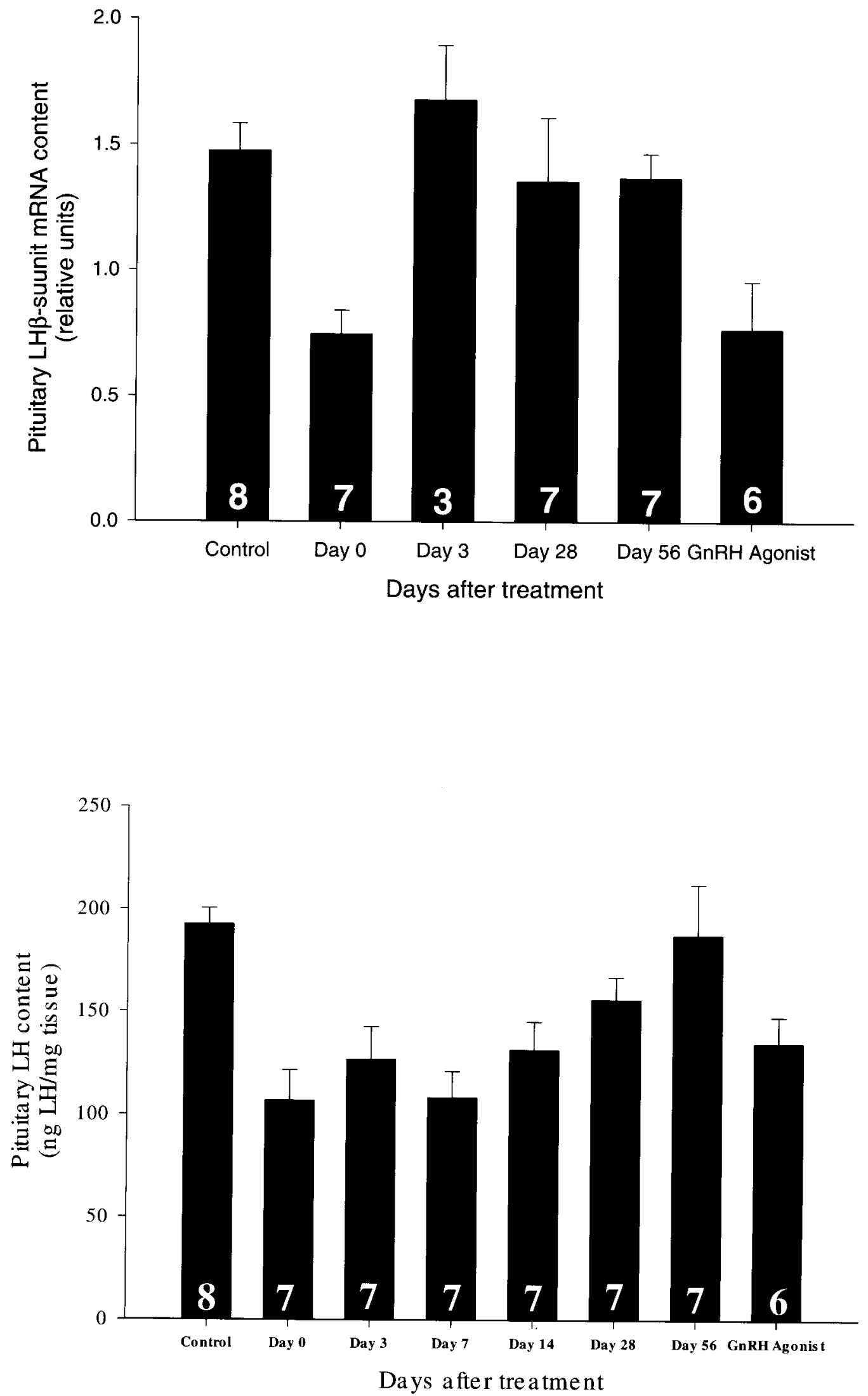
secretion. This could represent another post-transcription regulation point that influences the ultimate action of a hormone subsequent to gene activation.

\section{Summary}

The aim in this review has been to draw attention to post-transcription regulation of mRNA, with a particular emphasis on the anterior pituitary gland. The control of mRNA translation, and ultimately protein synthesis, can occur through a number of mechanisms and these could be considered to introduce a second order of control of gene function. In this review the recovery of gonadotrope cell function after therapy with a GnRH agonist was used as a model to study the relationships between pituitary contents of LH $\beta$-subunit mRNA and LH. It was found that LH $\beta$-subunit mRNA returned to normal levels relatively quickly after therapy with a GnRH agonist, whereas pituitary content of $\mathrm{LH}$ took longer to return to normal levels. This finding was interpreted as providing evidence that $\mathrm{LH}$ biosynthesis can involve posttranscription regulation of $\mathrm{LH} \beta$-subunit mRNA. It could be argued that the function of gonadotrope cells during and after therapy with a GnRH agonist represents a pharmacological situation that may not reflect cellular events that occur under normal conditions. However, it may be necessary to use different experimental models to gain insight into mechanisms of post-transcription regulation of mRNA that may not be apparent under normal situations, but which are nevertheless important for cellular functions. With regard to gonadotrope cells, post-transcription regulation of mRNAs may be associated with the integrated response of these cells to stimulation by GnRH and feedback mechanisms imposed by the gonads. The multiple effector pathways in gonadotrope cells makes them ideal model cells to study the molecular mechanisms of post-transcription regulation of mRNAs. It is anticipated that post-transcription regulation of mRNAs will become recognized as an important feature of cellular biosynthetic processes, particularly with regard to cells of the anterior pituitary.

\section{References}

Alberts B, Bray D, Lewis J, Raff M, Roberts K, Watson J. Molecular Biology of the Cell. 3rd ed. New York: Garland Publishing, 1994.

Aspden WJ, Rao A, Scott PT, Clarke IJ, Trigg TE, Walsh J, D'Occhio MJ. Direct actions of the luteinizing hormone-releasing hormone agonist deslorelin, on anterior pituitary contents of luteinizing hormone $(\mathrm{LH})$ and follicle stimulating hormone (FSH), LH and FSH subunit messenger ribonucleic acid, and plasma concentrations of LH and FSH in castrated male cattle. Biol Reprod 1996;55:386-92.

Aspden WJ, Rao A, Rose K, Scott PT, Clarke IJ, Trigg TE, Walsh J, D'Occhio MJ. Differential responses in anterior pituitary luteinizing hormone (LH) content and 
LHB- and $\alpha$-subunit mRNA, and plasma concentrations of LH and testosterone, in bulls treated with the LH-releasing hormone agonist deslorelin. Dom Anim Endocrinol 1997a; 14:429-37.

Aspden WJ, van Reenen N, Whyte TR, Maclellan LJ, Scott PT, Trigg TE, Walsh J, D'Occhio MJ. Increased testosterone secretion in bulls treated with a luteinizing hormone releasing hormone (LHRH) agonist requires endogenous LH but not LHRH. Dom Anim Endocrinol 1997 ${ }^{\mathrm{b}}$; 14:421-8.

Beckers NC, Laven JS, Eijhemans MJ, Fauser BC. Follicular and luteal phase characteristics following early cessation of gonadotropin-releasing hormone agonist during ovarian stimulation for in vitro fertilization. Hum Reprod 2000; 15:43-9.

Benard O, Naor Z, Seger R. Role of dynamin, Src and Ras in the PKC-mediated activation of ERK by gonadotropin-releasing hormone. J Biol Chem 2000 (in press).

Bergfeld EGM, D'Occhio MJ, Kinder JE. Pituitary function, ovarian follicular growth, and plasma concentrations of $17 \beta$-oestradiol and progesterone in prepubertal heifers during and after treatment with the luteinizing hormone-releasing hormone agonist deslorelin. Biol Reprod 1996; ;4:776-82.

Bergfeld EGM, D'Occhio MJ, Kinder JE. Continued desensitization of the pituitary gland in bulls after treatment with the luteinizing hormone-releasing hormone agonist deslorelin. Biol Reprod 1996 ;54:769-75.

Bertschinger $\mathrm{Hj}$, Asa ChS, Calle PP, Long JA, Jochle W. Control of reproduction and sex behaviour in exotic wild carnivores with the GnRH agonist deslorelin. Advances in Dog, Cat and Carnivore Reproduction. $4^{\text {th }}$ International Symposium on Canine and Feline Reproduction and $2^{\text {nd }}$ Congress of the European Veterinary Society for Small Animal Reproduction, 29 June - 1 July, Oslo, Norway 2000;22.

Bouamoud N, Lerrant Y, Ribot G and Counis R. Differential stability of mRNAs encoding for $\alpha$ and gonadotrophin $\beta$ subunits in cultured rat pituitary cells. Mol Cell Endocrinol 1992;88:143-51.

Brooks SA, Rigby WF. Characterization of the mRNA ligands bound by the RNA binding protein hnRNP A2 utilizing a novel in vivo technique. Nucleic Acids Res 2000;28:E49.

Calado A, Kutay U, Kuhn U, Wahle E, Carmo-Fonseca M. Deciphering the cellular pathway for transport of poly(A)-binding protein II. RNA 2000;6:245-56.

Chedrese PJ, Kay TWH, Jameson JL.Gonadotropin-releasing hormone stimulates glycoprotein hormone alpha-subunit messenger ribonucleic acid (mRNA) levels in alpha T3 cells by increasing transcription and mRNA stability. Endocrinology 1994; 134:2475-81.

Clayton RN. Gonadotropin-releasing hormone: Its actions and receptors. J Endocrinol 1989;120:11-19.

Conn PM. The molecular basis of gonadotropin-releasing hormone action. Endocr Rev 1986;7:3-10. 
Conn PM, Janovick JA, Stanislaus D, Kuphal D, Jennes L. Molecular and cellular bases of gonadotropin-releasing hormone action in the pituitary and central nervous system. Vitam Horm 1995;50:151-214.

Cornea A, Janovick JA, Maya-Nunez G, Conn PM. Gonadotropin releasing hormone microaggreggation: rate monitored by fluorescence resonance energy transfer. $J$ Biol Chem 2000 (in press).

Counis R, Jutisz M. Regulation of pituitary gonadotropin gene expression: outline of intracellular pathways. TEM 1991;2:181-6.

Dan-Cohen $H$, Ben-Menahem D, Naor $Z$. The gonadotropin-releasing hormone receptor: signals involved in gonadotropin secretion and biosynthesis. Horm Res 1990;33:76-86.

Deo RC, Bonanno JB, Sonenberg N, Burley SK. Recognition of polyadenylate RNA by the poly(A)-binding protein. Cell 1999;98:835-45.

Dever TE. Translation initiation: adept at adapting. Trends Biochem Sci 1999;24:398403.

Diamond DJ, Goodman HM. Regulation of growth hormone messenger RNA synthesis by dexamethasone and triodthyronine: transcriptional rate and mRNA stability changes in pituitary tunmor cells. J Mol Biol 1985;181:41-62.

D'Occhio MJ, Aspden WJ. Characteristics of luteinizing hormone (LH) and testosterone secretion, pituitary responses to LH-releasing hormone (LHRH) and reproductive function in young bulls receiving the LHRH agonist deslorelin: effect of castration on LH responses to LHRH. Biol Reprod 1996;54:45-52.

D'Occhio MJ, Aspden WJ. Endocrine and reproductive responses of male and female cattle to agonists of gonadotropin-releasing hormone. $J$ Reprod Fert 1999;54(suppl): 101-14.

D'Occhio MJ, Aspden WJ, Whyte TR. Controlled reversible suppression of estrous cycles in beef heifers and cows using agonists of gonadotropin-releasing hormone. J Anim Sci 1996;74:218-25.

D'Occhio MJ, Fordyce G, Whyte TR, Aspden WJ, Trigg TE. Reproductive responses of cattle to GnRH agonists. Anim Reprod Sci 2000;60-61:433-42

D'Occhio MJ, Jillella D, Lindsey BR. Factors that influence follicle recruitment, growth and ovulation during ovarian superstimulation in heifers: Opportunities to increase ovulation rate and embryo recovery by delaying the exposure of follicles to LH. Theriogenology 1999;51:9-35.

Gharib SD, Wierman ME, Shupnik MA, Chin WW. Molecular biology of the pituitary gonadotropins. Endocr Rev 1990;11:177-99.

Gong JG, Bramley TA, Gutierrez CG, Peters AR, Webb R. Effects of chronic treatment with a gonadotropin-releasing hormone agonist on peripheral concentrations of FSH and LH, and ovarian function in heifers. J Reprod Fert 1995;105:263-70.

Gong JG, Campbell BK, Bramley TA, Gutierrez CG, Peters AR, Webb R. Suppression in the secretion of follicle-stimulating hormone and luteinizing hormone, and ovarian follicle development in heifers continuously infused with a gonadotropinreleasing hormone agonist. Biol Reprod 1996;55:68-74. 
Greenspan FS, Strewler GJ. Basic and Clinical Endocrinology. 5th ed. Stamford, Connecticut: Appleton and Lange, 1997.

Grosset C, Chen CY, Xu N, Sonenberg N, Jacquemin-Sablon H, Shyu AB. A mechanism for translationally coupled mRNA turnover: interaction between the poly(A) tail and a c-fos RNA coding determinant via a protein complex. Cell 2000; 103:29-40.

Hazum E, Conn PM. Molecular mechanism of gonadotropin releasing hormone (GnRH) action I. The GnRH receptor. Endocr Rev 1988;9:379-86.

Huckle WR, Conn PM. Molecular mechanism of gonadotropin releasing hormone action II. The effector system. Endocr Rev 1988;9:387-95.

Johnson MH, Everitt BJ. Essential Reproduction. London: Blackwell Science Limited, 2000.

Jones KA. HIV trans-activation and transcriptional control mechanisms. New Biol 1989;1:127-35.

Karp G. Cell and molecular biology: Concepts and experiments. 2nd ed. New York: John Wiley and Sons; 1999.

Karten MJ, Rivier JE. Gonadotropin-releasing hormone analog design. Structurefunction studies towards the development of agonists and antagonists: Rationale and perspectives. Endocr Rev 1986;7:44-66.

Kimura N, Arai K, Sahara Y, Suzuki H, Kimura N. Estradiol transcriptionally and posttranscriptionally up-regulates thyrotropin-releasing hormone receptor messenger ribonucleic acid in rat pituitary cells. Endocrinology 1994;134:432-40.

Kislaushis EH, Singer RU. Determinants of mRNA localization. Curr Opin Cell Biol 1992;4:975-8.

Kornblihtt AR. The fibronectin gene as a model for splicing and transcription studies. FASEB J 1996;10:248-57.

Korneeva NL, Lamphear BJ, Hennigan FL, Merrick WC, Rhoads RE. Characterization of the two eIF4A binding sites on human eIF4G-1. J Biol Chem 2000 (in press).

Leedman PJ, Stein AR, Chin WW. Regulated specific protein binding to a conserved region of the 3'-untranslated region of thyrotropin $\beta$-subunit mRNA. Mol Endocrinol 1995;9:375-87.

Levy A, Lightman SL. Bromocriptine reduces rat thyrotropin $\beta$-subunit mRNA stability. J Endocrinol Investigat 1990;13:49-53.

Lin X, Conn PM. Transcriptional activation of gonadotropin-releasing hormone (GnRH) receptor gene by GnRH: involvement of multiple signal transduction pathways. Endocrinology 1999;140:358-64.

McArdle CA, Davidson JS, Willars GB. The tail of the gonadotropin releasing hormone receptor: desensitization at, and distal to, G protein coupled receptors. Mol Cell Endocrinol 1999;151:129-36.

McKeown M. Alternative mRNA splicing. Ann Rev Cell Biol 1992;8:133:55.

Melefors $O$, Hentze MW. Translational regulation by mRNA protein interactions in eukaryotic cells: ferritin and beyond. Bioessays 1993;15:85-90. 
Melson BE, Brown JL, Schoenemann HM, Tarnavsky GK, Reeves JJ. Elevation of serum testosterone during chronic LHRH agonist treatment in the bull. $\mathrm{J}$ Anim Sci 1986;62:199-207.

Munson L, Asa CS, Bauman J, Jochle W, Trigg TE. Effects of the GnRH-analog deslorelin on oestrous cycle, behavior and health of cats in a controlled trial. Advances in Dog, Cat and Carnivore Reproduction. $4^{\text {th }}$ International Symposium on Canine and Feline Reproduction and $2^{\text {nd }}$ Congress of the European Veterinary Society for Small Animal Reproduction, 29 June - 1 July, Oslo, Norway 2000;23.

Naor, Z. Signal transduction mechanisms of $\mathrm{Ca}^{2+}$ mobilising hormones: The case of gonadotropin-releasing hormone. Endocr Rev 1990;11:326-53.

Paek I, Axel R. Glucocorticoids enhance the stability of growth hormone mRNA. Mol Cell Biol 1987;7:1496-1507.

Park D, Cheon M, Kim C, Kim K, Ryu K. Progesterone together with estradiol promotes luteinizing hormone $\beta$-subunit mRNA stability in rat pituitary cells cultured in vitro. Eur J Endocrinol 1996;134:236-42.

Paul SJ, Ortolano GA, Haisenleder DJ, Stewart JM, Shupnik MA, Marshall JC. Gonadotropin subunit messenger RNA concentrations after blockade of gonadotropin-releasing hormone action: testosterone selectively increases follicle stimulating hormone $\beta$-subunit messenger RNA by posttranscriptional mechanisms. Mol Endocrinol 1990;4:1943-55.

Pyronnet S. Phosphorylation of the cap-binding protein eIF4E by the MAPK-activated protein kinase mnk1. Biochem Pharmacol 2000;15:1237-43.

Rio DC. RNA binding proteins, splice site selection and alternative pre-mRNA splicing. Gene Express 1992;2:1-5.

Sealfon, S.C., Weinstein, H. and Millar, R.P. 1997. Molecular Mechanisms of ligand interaction with the gonadotropin-releasing hormone receptor. Endocr Rev 1997;18:180-205.

Shacham S, Cheifetz MN, Lewy H, Ashkenazi IE, Becker OM, Seger R, Naor Z. Mechanisms of GnRH receptor signaling: from the membrane to the nucleus. Ann Endocrinol 1999;60:79-88.

Shupnik MA, Ridgeway EC, Chin WW. Molecular biology of thyrotropin. Endocr Rev $1989 ; 10: 459-75$.

Staton JS, Leedman PJ. Posttranscriptional regulation of thyrotropin $\beta$-subunit messenger ribonucleic acid by thyroid hormone in murine thyrotrope tumor cells: a conserved mechanism across species. Endocrinology 1998;139:1093-1100.

Staton JM, Thomson AM, Leedman PJ. Hormonal regulation of mRNA stability and RNA-protein interaction in the pituitary. $J$ Mol Endocrinol 2000;25:17-34.

Stevens A. Eukaryotic nucleases and mRNA turnover. In: Belasco J, Brawerman G, eds. Control of messenger RNA stability. San Diago: Academic Press, 1993;44971.

St. Johnston D. The intracellular localization of messenger RNA. Cell 1995;81:16170. 
Stojilkovic SS, Reinhart J, Catt KJ. Gonadotropin-releasing hormone receptors: structure and signal transduction pathways. Endocr Rev 1994;15:462-99.

Theill LE, Karim M. Transcriptional control of GH expression and anterior pituitary development. Endocr Rev 1993;14:670-89.

Thompson AM, Rogers JT, Leedman PJ. Iron-regulatory proteins, iron-responsive elements, and ferritin translation. Int $\mathrm{J}$ Biochem Cell Biol 1999;31:1139-52.

Trigg TE, Wright PJ, Armour AF, Williamson PE, Junaidi A, Martin GB, Walsh J. Long term reversible desexing of male dogs and oestrus postponement of bitches, using a GnRH analogue implant. Advances in Dog, Cat and Carnivore Reproduction. $4^{\text {th }}$ International Symposium on Canine and Feline Reproduction and $2^{\text {nd }}$ Congress of the European Veterinary Society for Small Animal Reproduction, 29 June -1 July, Oslo, Norway 2000;21.

Wakiyama M, Imataka $\mathrm{H}$, Sonenberg $\mathrm{N}$. Interaction of eIF4G with ploy(A)-binding protein stimulates translation and is critical for xenopus oocyte maturation. Curr Biol 2000;21:1147-50.

Wang Z, Day N, Trifillis P, Kiledjian M. An mRNA stability complex functions with poly(A)-binding protein to stabilize mRNA in vitro. Mol Cell Biol 1999;19:4552-60.

Wang $Z$, Kiledjian $M$. The poly(A)-binding protein and an mRNA stability protein jointly regulate an endoribonuclease activity. Mol Cell Endocrinol 2000;20:633441.

Weaver R. Molecular Biology. Boston: McGraw-Hill, 1999. 